\title{
Homer2 and Alcohol: A Mutual Interaction
}

\author{
Valentina Castelli, Anna Brancato, Angela Cavallaro, Gianluca Lavanco \\ and Carla Cannizzaro*
}

Department of Sciences for Health Promotion and Mother and Child Care "G. D'Alessandro", University of Palermo, Palermo, Italy

The past two decades of data derived from addicted individuals and preclinical animal models of addiction implicate a role for the excitatory glutamatergic transmission within the mesolimbic structures in alcoholism. The cellular localization of the glutamatergic receptor subtypes, as well as their signaling efficiency and function, are highly dependent upon discrete functional constituents of the postsynaptic density, including the Homer family of scaffolding proteins. The consequences of repeated alcohol administration on the expression of the Homer family proteins demonstrate a crucial and active role, particularly for the expression of Homer2 isoform, in regulating alcohol-induced behav-

OPEN ACCESS

Edited by: Marijn Lijffijt, Baylor College of Medicine, United States

Reviewed by: Karen K. Szumlinski, University of California, Santa Barbara, United States Tod Edward Kippin, University of California, Santa Barbara, United States

${ }^{*}$ Correspondence: Carla Cannizzaro carla.cannizzaro@unipa.it

Specialty section: This article was submitted to Addictive Disorders, a section of the journal Frontiers in Psychiatry

Received: 25 August 2017 Accepted: 17 November 2017 Published: 30 November 2017

Citation: Castelli V, Brancato A, Cavallaro A Lavanco G and Cannizzaro C (2017) Homer2 and Alcohol: A Mutual Interaction.

Front. Psychiatry 8:268. doi: 10.3389/fpsyt.2017.00268 ioral and cellular neuroplasticity. The interaction between Homer2 and alcohol can be defined as a mutual relation: alcohol consumption enhances the expression of Homer2 protein isoform within the nucleus accumbens and the extended amygdala, cerebral areas where, in turn, Homer2 is able to mediate the development of the "pro-alcoholic" behavioral phenotype, as a consequence of the morpho-functional synaptic adaptations. Such findings are relevant for the detection of the strategic molecular components that prompt alcohol-induced functional and behavioral disarrangement as targets for future innovative treatment options.

Keywords: alcohol, Homer proteins, Homer2, glutamate, addiction

\section{INTRODUCTION}

Chronic and excessive alcohol consumption is associated with several neuropsychiatric effects, such as impairment in judgment, learning, memory, perception, and motor coordination $(1,2)$ characterized by aberrant morpho-functional plasticity at the synaptic level (3). However, the neurobiological mechanism underpinning the pharmacological properties of alcohol and its biologically active adduct is complex and not completely elucidated yet, thus hampering the development of successful pharmacological therapies (4-10). In the central nervous system, a large variety of signals and neurotransmitters [e.g., dopamine (DA), serotonin, glutamate, GABA, opioids, endocannabinoids] play a prominent role in mediating the behavioral and pharmacological effects of alcohol (11-21). Most of them converge on the mesolimbic DA reward circuitry (22-25), a main hub in the mediation of the reinforcing effects of drugs of abuse. At a molecular level, alcohol,

Abbreviations: AMPAR, 5-methyl-4-isoxazolepropionate receptor; SER, smooth endoplasmic reticulum; GKAP, guanylate kinase-associated protein; GRIP, glutamate receptor interacting protein; mGluR, metabotropic glutamate receptor; NMDAR, $N$-methyl-D-aspartate receptor; VDCC, voltage-dependent $\mathrm{Ca}^{2+}$ channel. 
as well as its first metabolite acetaldehyde, has been shown to directly affect DA neurotransmission in the mesolimbic system by increasing neuronal firing in the ventral tegmental area and stimulating DA release in the nucleus accumbens shell (NACsh) (26-28). Beside DA transmission, the endogenous opioid and the endocannabinoid systems have been reported to contribute to alcohol-related behaviors, in particular, voluntary consumption, reward and relapse behavior, both in preclinical models (29) and in humans $(30,31)$. Both modulatory pathways fine tune incoming inputs to the limbic brain regions $(32,33)$ and, among them, primarily the excitatory amino acid glutamate efferents $(34,35)$.

Intact glutamate signaling is critical for motivation and reward, learning and memory, and cognitive performance, just those functions that are essentially altered in alcohol-dependent individuals $(21,36)$. Alcohol exposure, in fact, reshapes both pre- and postsynaptic excitatory neurotransmission within mesolimbic structures, prompting a hyperglutamatergic state that contributes to the development and expression of alcohol dependence (37-39). The discrete functional components of the postsynaptic density (PSD) at the glutamatergic synapse, in particular, contribute to the cellular localization, trafficking, and efficiency of the glutamatergic receptor subtypes. Alterations in their expression within the NAC and amygdala (Amy) might gate the development of alcohol-induced behavioral plasticity, focusing on PSD components as crucial interceders of the acute and chronic effects of alcohol $(34,40)$. Notably, among the postsynaptic scaffolding proteins, the Homer family has been largely characterized and highlighted as a primarily plasticity-conditioning element (41-46). In particular, preclinical and clinical data point to Homer2 isoform proteins as essential and active players in the expression of alcohol-induced behavioral and cellular plasticity (44, 47-51).

This review summarizes the physiological role played by Homer proteins as a whole, with an emphasis on the most recent evidence on Homer2 isoforms. In particular, we will show the key role played by Homer2 isoforms within the glutamatergic signaling in the modulation of the acute behavioral and neurochemical sensitivity to alcohol, the development of alcohol-induced neuroplasticity, as well as other pathological phenotypes associated with alcohol addiction.

\section{THE HOMERS}

The Homer family, a dendritically enriched scaffold protein group, is predominantly localized at the PSD in mammalian neurons where they contribute to the maintenance of synaptic functional integrity (52-54). The Homer genes can give rise to both constitutively expressed- and immediate early gene-products, which are induced by both physiological and abnormal neuronal activity (52). Alternative splicing results in multiple transcript variants, classified primarily into: long forms (Homer1b/c, Homer2a/b, and Homer3a/b), which represent the constitutively expressed isoforms; short forms, which represent the activity-dependent splice variants of the Homer1 gene (Homerla and Ania3) (54, 55). All Homer proteins, through their $\mathrm{N}$-terminal domain, bind a specific short proline-rich amino acid sequence found in several signaling proteins: Group1 of metabotropic glutamate receptors (mGluRs); $\mathrm{Ca}^{2+}$-signaling-related proteins, including phospholipase C- $\beta$ (PLCß), inositol 1,4,5-trisphosphate receptors, ryanodine receptors, transient receptor potential canonical ion channels; PSD scaffolding proteins, such as Shank component of the NMDA receptor-associated PSD-95 complex (52-54, 56-61). The binding to these molecules allows Homers to serve as a postsynaptic scaffold that crosslinks and, thus, regulates the functionality of the ligands (Figure 1) (62). Long Homer isoforms additionally encode a C-terminal coiled-coil (C-C) domain, which allows their multimerization at a specific site or subcellular compartment, such as the actin cytoskeleton (55). Synaptic multimerization of long Homer proteins probably regulates or facilitates signal transduction or cross-talk between target proteins; on the other hand, declustering of Homer is induced by an increase in intracellular $\mathrm{Ca}^{2+}$ concentration through NMDA receptors or voltage-dependent $\mathrm{Ca}^{2+}$ channels. In response to synaptic activity, reversible clustering and declustering of the Homer complex is probably an important mechanism used to alter the molecular composition within the complex, so that cross-talk signaling among cross-linked target proteins can be regulated (54). The short Homer isoforms lack the C-C domain and, therefore, cannot form multimers and functionally compete with the long Homer isoforms in binding postsynaptic signaling proteins (63). In this way, they act as a natural dominant-negative regulator of the long Homers, causing rapid disruption of long Homer clusters and, consequently, affecting synaptic architecture $(53,59,64)$.

Due to their structural and functional presence in glutamate synapses, both immediate early gene and constitutively expressed Homer isoforms have been extensively involved in calcium signaling and behavioral pathologies associated with neuropsychiatric and neurodegenerative disorders, such as drug addiction, depression, anxiety, epilepsy and schizophrenia, Parkinson's and Alzheimer's disease (65-72). Some examples concern the deletion of Homer1, but not of Homer2, in the enhanced expression of certain anxiety- and depression-related behaviors in mice $(73,74)$; the blunted induction of Homerla upon excessive synaptic activity as a putative mechanism in the etiology of epilepsy (75); Homer1 polymorphisms have a role in the etiology of schizophrenia, and Homer1-knockout (KO) mice exhibit behavioral and neurochemical abnormalities consistent with a schizophrenialike phenotype; furthermore, the putative increase in Homer la in the forebrain is indicated as part of the therapeutic and side-effect profiles of antipsychotic drugs (76-79). Homer proteins exhibit diverse regulatory roles in behavior and, among them, they seem to take part in sensitization to psychostimulant drugs, induction, and maintenance of excessive alcohol consumption, and addiction (80). In particular, low levels of Homer1 and Homer2 seem to represent an important molecular adaptation, associated with behavioral and neurochemical sensitivity to cocaine $(81,82)$. In this regard, a more comprehensive overview of Homer proteins implication in a wide variety of neuropsychiatric abnormalities can be found in Ref. (83). Recently, "novel" Homer2-interacting proteins have been detected, as part of the signaling cascade that is activated by the glutamatergic transmission, thus expanding 


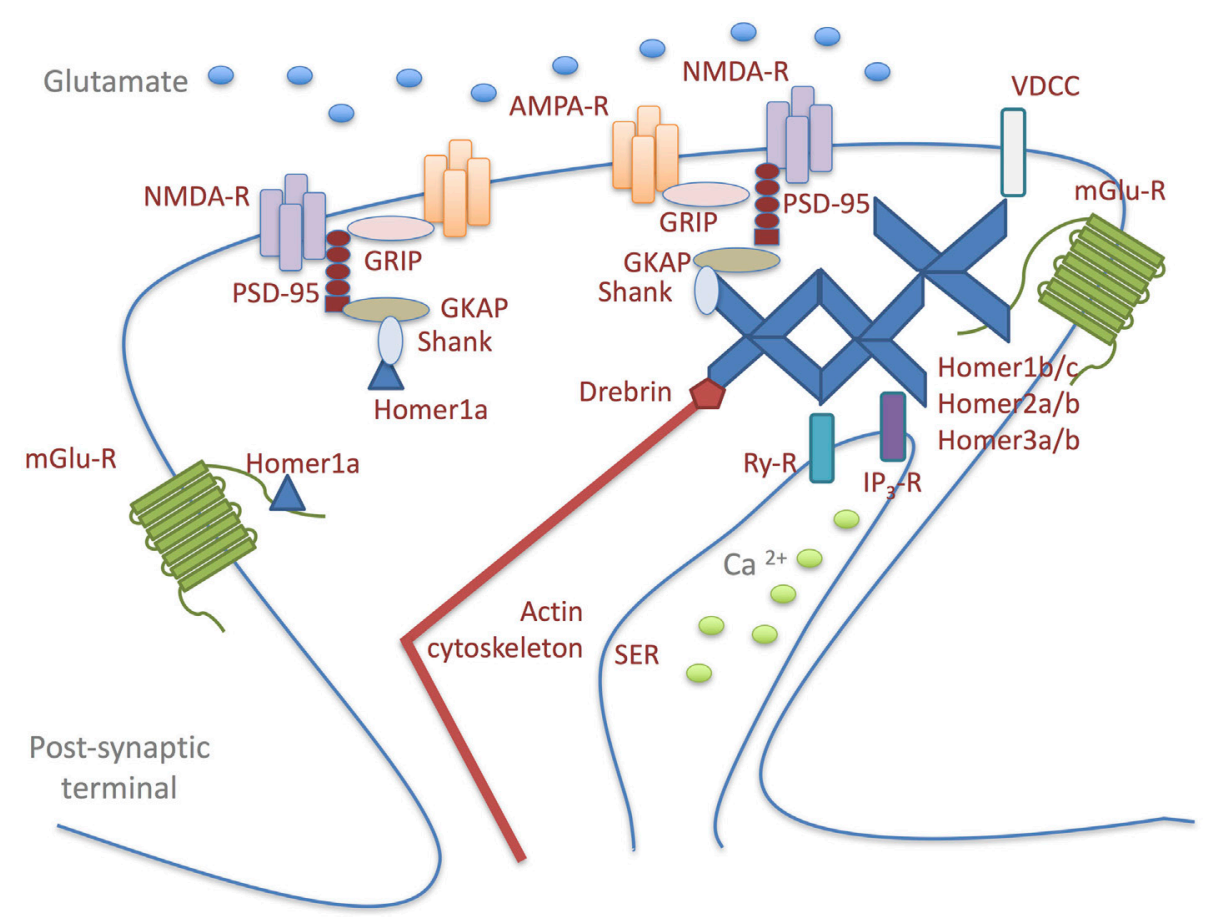

FIGURE 1 | Homer proteins form a physical link among signaling molecules in glutamatergic postsynaptic density (PSD). Long Homer forms (Homer1b/C; Homer2a/b; Homer3a/b) bind to each other through their carboxy-terminal domains and to the target proteins: Group1 of metabotropic glutamate receptors (mGluRs); Ca ${ }^{2+}$-signaling-related proteins, including phospholipase C-B (PLCB), inositol 1,4,5-trisphosphate receptors (IP $\left.{ }_{3}-\mathrm{R}\right)$, ryanodine receptors (Ry-R), transient receptor potential canonical ion channels [voltage-dependent $\mathrm{Ca}_{2}^{+}$channel (VDCC)]; PSD scaffolding proteins, such as Shank component of the NMDA receptorassociated PSD-95 complex. The binding to these molecules allows Homers to serve as a postsynaptic scaffold that crosslinks and, thus, regulates the functionality of the ligands. Long Homer isoforms additionally encode a C-terminal coiled-coil domain, which allows their multimerization at a specific site or subcellular compartment, such as the actin cytoskeleton. Synaptic multimerization of long Homer proteins probably regulates or facilitates signal transduction or cross-talk between target proteins. The short Homer isoform (Homer1a) lacks the coiled-coil domain and, therefore, cannot form multimers and functionally compete with the long Homer isoforms in binding postsynaptic signaling proteins. In this way, Homer1a acts as a natural dominant-negative regulator of the long Homers, causing rapid disruption of long Homer clusters and, consequently, affecting synaptic architecture.

the network of proteins that potentially contribute to the behavioral abnormalities associated with alcohol abuse $(84,85)$.

\section{HOMER2 AND ALCOHOL: THE INTERACTION}

Among the Homer isoforms, Homer2 has been shown to be critically important for plasticity in multiple models of alcohol abuse (44, 47-51, 86, 87). Homer2 expression is sensitive to alcohol experience. Even a first alcohol drink is sufficient to induce synaptic plasticity in NACsh D1-positive neurons where it increases synaptic expression of the scaffolding protein Homer2 and GluA1 5-methyl-4-isoxazolepropionate receptor subunit, via enhanced mammalian target of rapamycin complex 1-dependent RNA-toprotein translation (88). The increase in Homer2 levels has also been shown employing animal models of alcohol dependence and withdrawal, within brain regions relevant to addiction, and has been accompanied by functional alterations of glutamatergic synapses. In particular, a robust increase in Homer2 levels at 2 days, 2 weeks, and 2 months has been reported following withdrawal from chronic alcohol consumption within NAC, and was accompanied by a less enduring elevation in total mGluR1 and GluNR2b levels (48). Along with these results, short- and long-term withdrawal from intermittent and continuous alcohol consumption substantially increase Homer2a/b, mGluRs, as well as GluNR2a and GluNR2b subunits in the core (NACc), whereas slightly change GluNR2a and GluNR2b expression within the NACsh (89). Moreover, increased Homer2a/b, mGluR1, and GluNR2b expression have been detected in the central Amy (ceAmy), in both withdrawal groups, but not in the basolateral region, suggesting that withdrawal from chronic alcohol consumption produces enduring increase in the efficiency of postsynaptic glutamate receptor signaling that persists well beyond the time when signs of physical withdrawal have dissipated (89). Shortterm withdrawal $(24 \mathrm{~h})$ from a chronic 30 -day binge drinking period also increases Homer $2 \mathrm{a} / \mathrm{b}$ and PLCß expression within the ceAmy, concomitant with increased mGluR1 and GluN2B, not affecting the expression of correlated protein expression within the adjacent basolateral Amy (87). On the other hand, one recent research shows that, at $24 \mathrm{~h}$ withdrawal after 14 consecutive days of binge-drinking under 4-bottle drinking-in-the-dark (DID) procedures, both adult mice with prior history of binge-drinking during adolescence and adult mice without drinking history 
display a significant decrease in ceAmy Homer2b expression (90). At the present time, it remains to clarify whether or not the opposite trend of findings reflects procedural differences related to the total duration of alcohol-access or to the number of bottles presented during alcohol-access. Finally, evidence exists on how binge alcohol drinking under the scheduled high alcohol consumption (SHAC) (86) and the DID procedures (49) affect the expression of glutamate signaling-related proteins within brain regions implicated in the neurobiology of alcoholism. SHAC procedure doubles NAC Homer2a/b expression, along with a smaller, albeit significant, increase in NAC levels of GluNR2a and GluNR2b (86); limited access to alcohol drinking under the DID procedure upregulates NACsh Homer2a/b levels, concomitant with increases in mGluR5 and GluNR2b (49). It is possible to theorize that an alcohol-induced increase in Homer2 signaling and, thus, in glutamate receptor plasticity, within both the "motor" (NACc) and "motive" (NACsh) striatal regions, and in ceAmy, is a pharmacodynamic response to alcohol that likely contributes to the propensity to further consume excessive amounts of alcohol $(44,84)$ (Table 1). In this regard, converging data derived from both human (51) and animal (44, 47-50) studies implicate Homer gene products in behavioral sensitivity to alcohol and addiction vulnerability. Researchers adopted numerous strategies to examine the critical role for Homer2 in maintaining alcohol consumption and promoting addiction. Virus-mediated NAC Homer2 overexpression augmented various aspects of alcoholrelated behavior in rodents $(48,50)$. In more detail, Szumlinski et al. (48) have shown that viral transfection of NAC neurons with an adeno-associated virus (AAV) carrying Homer2b in alcohol-preferring C57BL6/J (B6) inbred mice enhances behavioral output for alcohol in an operant self-administration paradigm and facilitates the expression of an alcohol-conditioned place-preference. Moreover, following an acute alcohol injection, NAC Homer2 overexpression facilitated NAC glutamate- and DA release and augmented alcohol-induced DA and glutamate sensitization. Since ceAmy dysfunction is critically implicated in alcohol withdrawal-induced negative affect, changes in Homer2 protein levels within this region closely align with the manifestation of a negative affective state, including the incubation of an adverse condition in those with a history of adolescent-onset binge-drinking. AAV Homer2-cDNA infusion reversed the hyperanxious phenotype in adolescent-onset alcohol-drinking mice during protracted withdrawal and reduced subsequent alcohol consumption. Conversely, Homer2-cDNA was anxiogenic and significantly increased drinking in alcohol-inexperienced mice (91). Thus, Homer2 overexpression is functionally correlated to an increase in alcohol potency and efficacy to elicit reward, through an enhancement in both appetitive and consummatory alcohol-related behavior, mediated by the role of Homer 2 expression in gating the negative reinforcing properties of alcohol that drive excessive intake. Conversely, Homer2 deletion [knockout (KO)], knockdown, or blockade result in an alcohol-avoiding phenotype $(47,49,50)$. In particular, Homer2 knockout (H2KO) mice display a lower preference for alcohol versus water in the preference test, than the wild-type (WT) mice, and exhibit place aversion after alcohol-place conditioning. It appears, therefore, that $\mathrm{H} 2 \mathrm{KO}$ mice display a deficient behavioral plasticity to alcohol. This is accompanied by inhibition of the raise in extracellular DA and glutamate release within the NAC, after repeated injections of alcohol (47). The Homer2 scaffolding is essential to observe the modulatory effects of mGlu1/5-protein kinase $\mathrm{C}(\mathrm{PKC}) \varepsilon$ and PLC signaling on voluntary alcohol intake. As consistently described, whereas the infusion of mGluR1 antagonist into the NACsh, the intra-ceAmy infusion of mGluR1, mGluR5, and PLC inhibitors (87) and inhibition of PKC $\varepsilon$ translocation within both ceAmy and NAC (92) dose-dependently reduce alcohol consumption in $\mathrm{B} 6$ and Homer2 WT mice, this effect is not present in $\mathrm{H} 2 \mathrm{KO}$ animals $(44,87)$. Even knocking-down Homer2 levels within the NACsh (49) and ceAmy (87) affect alcohol consumption: it has been shown that Homer2b knockdown significantly reduced alcohol intake in the DID model and, later on, under the DID four-bottle-choice procedure at $40 \%$ alcohol.

Finally, complementing prior findings from mouse models of alcohol vulnerability, data from Haider and colleagues indicate that Homer2 within the NACc bidirectionally regulates alcohol intake in both alcohol-preferring (P) and Wistar rats. They have employed an AAV strategy to overexpress and knock down Homer2b within the rat NAC, under continuous-access alcohol drinking. Homer2b overexpression elevates, while Homer2b knockdown reduces alcohol intake in both lines in a

TABLE 1 | The effects of alcohol treatments in rodents on Homer2 isoform levels.

\begin{tabular}{|c|c|c|c|c|c|}
\hline Procedure & Animal & Tissue & $\begin{array}{l}\text { Detection } \\
\text { technique }\end{array}$ & $\begin{array}{l}\text { Effect on Homer2 } \\
\text { levels }\end{array}$ & Reference \\
\hline $\begin{array}{l}\text { Protracted alcohol withdrawal after chronic } \\
\text { alcohol consumption }\end{array}$ & C57BL/6J (B6) mice & NAC & Immunoblotting & Robust increase & Szumlinski et al. (48) \\
\hline $\begin{array}{l}\text { Short- versus long-term withdrawal (SW or LW) } \\
\text { from ethanol consumption }\end{array}$ & $P$ rats & $\begin{array}{l}\text { Nucleus accumbens } \\
\text { shell (NACsh) } \\
\text { ceAmy and NACc }\end{array}$ & $\begin{array}{l}\text { Immunoblotting } \\
\text { Immunoblotting }\end{array}$ & $\begin{array}{l}\text { Limited changes } \\
\text { Substantial changes }\end{array}$ & Obara et al. (89) \\
\hline $\begin{array}{l}\text { Scheduled high alcohol consumption (SHAC) } \\
\text { procedure }\end{array}$ & C57BL/6J (B6) mice & NAC & Immunoblotting & Doubling & Cozzoli et al. (86) \\
\hline Drinking-in-the-Dark (DID) procedure & C57BL/6J (B6) mice & NACsh & Immunoblotting & Upregulation & Cozzoli et al. (49) \\
\hline $\begin{array}{l}\text { Short-term withdrawal from a chronic history of } \\
\text { binge drinking }\end{array}$ & C57BL/6J (B6) mice & ceAmy & Immunoblotting & Increase & Cozzoli et al. (87) \\
\hline 4-bottle DID procedure & C57BL/6J (B6) mice & ceAmy & Immunoblotting & Decrease & Lee et al. (90) \\
\hline
\end{tabular}


TABLE 2 | The effect of the alterations of Homer2 isoform on the alcoholic phenotype.

\begin{tabular}{|c|c|c|c|c|c|}
\hline Treatment & Test & Animal & Tissue & Data & Reference \\
\hline \multirow{8}{*}{$\begin{array}{l}\text { Adeno-associated } \\
\text { virus (AAV) carrying } \\
\text { Homer2b }\end{array}$} & Operant paradigm & C57BL/6J (B6) mice & NAC & Enhanced behavioral output for alcohol & Szumlinski et al. (48) \\
\hline & $\begin{array}{l}\text { Conditioned } \\
\text { place-preference }\end{array}$ & & & $\begin{array}{l}\text { Up-expression of an alcohol-conditioned } \\
\text { place-preference }\end{array}$ & \\
\hline & & & & Increase in glutamate and dopamine (DA) release & \\
\hline & $\begin{array}{l}\text { Ethanol place- } \\
\text { conditioning test }\end{array}$ & $\begin{array}{l}\text { Homer2 knockout } \\
(\mathrm{H} 2 \mathrm{KO}) \text { mice }\end{array}$ & NAC & Strong preference for water & Szumlinski et al. (47) \\
\hline & Ethanol versus water & & & Place aversion & \\
\hline & preference test & & & Locomotor depression; no behavioral adaptation & \\
\hline & & & & $\begin{array}{l}\text { No increase in extracellular levels of DA and } \\
\text { glutamate }\end{array}$ & \\
\hline & $\begin{array}{l}\text { Drinking-in-the-Dark } \\
\text { (DID) procedure }\end{array}$ & $\mathrm{H} 2 \mathrm{KO}$ mice & $\begin{array}{l}\text { Nucleus } \\
\text { accumbens } \\
\text { shell (NACsh) }\end{array}$ & Significant reduction in alcohol intake & Cozzoli et al. (49) \\
\hline \multirow{2}{*}{$\begin{array}{l}\text { Infusion of mGluR1 } \\
\text { antagonist }\end{array}$} & DID procedure & $\mathrm{H} 2 \mathrm{KO}$ mice & NACsh & Reduction of alcohol consumption & Lum et al. (44) \\
\hline & & C57BL/6J mice & & No reduction in alcohol consumption & \\
\hline \multirow[t]{2}{*}{ AAV-shRNA-Homer2b } & 4-bottle DID procedure & Homer knockdown & ceAmy & $\begin{array}{l}\text { Significant reduction at the highest alcohol } \\
\text { concentrations }\end{array}$ & Cozzoli et al. (87) \\
\hline & & $\begin{array}{l}\text { AAV-GFP-infused } \\
\text { controls }\end{array}$ & & No reduction in alcohol consumption & \\
\hline $\begin{array}{l}\text { Infusion of mGluR1, } \\
\text { mGluR5 and PLC } \\
\text { inhibitors }\end{array}$ & DID procedure & $\mathrm{H} 2 \mathrm{KO}$ mice & ceAmy & No effect in alcohol intake & Cozzoli et al. (87) \\
\hline AAV-cDNA-Homer2b & $\begin{array}{l}\text { Continuous alcohol } \\
\text { access procedure }\end{array}$ & $\begin{array}{l}\text { Alcohol-preferring } \mathrm{P} \text { rats } \\
\text { and Wistar rats }\end{array}$ & NACc & Elevation in alcohol intake & Haider et al. (50) \\
\hline AAV-shRNA-Homer2b & $\begin{array}{l}\text { Continuous alcohol } \\
\text { access procedures }\end{array}$ & $\begin{array}{l}\text { Alcohol-preferring } \mathrm{P} \text { rats } \\
\text { and Wistar rats }\end{array}$ & NACc & Reduction in alcohol intake & Haider et al. (50) \\
\hline $\begin{array}{l}\text { Inhibition of } \\
\text { protein kinase } \mathrm{C} \varepsilon \\
\text { translocation }\end{array}$ & $\begin{array}{l}\text { DID and SHAC } \\
\text { procedures }\end{array}$ & $\begin{array}{l}\text { H2KO mice } \\
\text { Homer2 wild-type mice }\end{array}$ & $\begin{array}{l}\text { NAC and } \\
\text { ceAmy }\end{array}$ & $\begin{array}{l}\text { No effect in alcohol intake } \\
\text { Inhibition of alcohol intake }\end{array}$ & Cozzoli et al. (92) \\
\hline \multirow[t]{2}{*}{ AAV-cDNA-Homer2 } & 3-bottle DID procedure & $\begin{array}{l}\text { Adolescent- } \\
\text { onset alcohol-drinking } \\
\text { mice }\end{array}$ & ceAmy & Reduction in alcohol consumption & Lee et al. (91) \\
\hline & & $\begin{array}{l}\text { Alcohol-inexperienced } \\
\text { mice }\end{array}$ & & Significant increase in alcohol consumption & \\
\hline
\end{tabular}

dose-dependent manner (50). Finally, the first study to examine the association between human alcohol use and the glutamatergic pathway-related genes shows that, among the others, genetic variations of Homer2 are associated with increased alcohol consumption in the Detroit Neighborhood Health Study (51).

These relevant findings point to Homer2-mediated organization of the glutamate synapse as a regulator of acute alcohol sensitivity and vulnerability (Table 2). These alterations, accompanied by spine structural abnormalities, are mainly restricted to the withdrawal phase of alcohol dependence, suggesting their relevance in the genesis of psychological and emotional signs and/or symptoms of acute abstinence (3).

\section{CONCLUSION}

Data reported provide evidence that alcohol drinking produces an enduring upregulation of the expression of specific components of the glutamate signaling cascade, in particular elevations in Homer2 levels. This neuroadaptation is proposed to contribute to the hyper-glutamatergic signaling that mediates alcohol-induced neuroplasticity within the NAC and Amy and promotes alcohol-related behaviors, sustaining the relapsing nature of alcohol abuse. Thus, the interaction between Homer2 and alcohol can be defined as a mutual relation: alcohol consumption enhances Homer2 protein isoforms expression within NAC and the extended Amy, cerebral areas where, in turn, Homer2 is able to mediate alcohol rewarding properties, leading to further alcohol consumption. This interaction is intertwined within the addiction cycle of alcohol: from the initial, voluntary, and single use, to the further repeated consumption and abuse, to addiction and withdrawal when increase in Homer2 signaling strength may promote relapse and further abuse.

The integrity of the PSD is important for normal spine morphology and activity-dependent adaptations of synaptic strength (93). A central question in neuroscience is how dendritic spines and synapses can be structurally and functionally modified to support experience-dependent changes in neuronal connectivity (64), leading to alcohol dependence. In this regard, the 
perturbation in the homeostasis of scaffolding proteins, first and foremost Homer2, has been associated with abnormal neuronal orientation, morphology, and axonal connections, which need to be further investigated in alcohol use disorder, in the early and late life stages. In particular, the assessment of the role of Homer proteins in vulnerability to drug abuse constitutes an unexplored research venue. Perinatal alcohol exposure (94) could alter Homer2 protein expression pattern, when the developing central nervous system is extremely sensitive to pharmacological and environmental manipulations (95-97).

Overall, these findings bridge preclinical and clinical knowledge regarding a role for Homer2 isoforms in regulating addiction vulnerability. Such evidence may help the detection of strategic molecular components that prompt alcohol-induced functional

\section{REFERENCES}

1. Cacace S, Plescia F, La Barbera M, Cannizzaro C. Evaluation of chronic alcohol self-administration by a 3-bottle choice paradigm in adult male rats. Effects on behavioural reactivity, spatial learning and reference memory. Behav Brain Res (2011) 219:213-20. doi:10.1016/j.bbr.2011.01.004

2. Cacace S, Plescia F, Sardo P, Cannizzaro C. Alcohol preference, behavioural reactivity and cognitive functioning in female rats exposed to a three-bottle choice paradigm. Behav Brain Res (2012) 234:11-9. doi:10.1016/j. bbr.2012.05.018

3. Spiga S, Talani G, Mulas G, Licheri V, Fois GR, Muggironi G, et al. Hampered long-term depression and thin spine loss in the nucleus accumbens of ethanoldependent rats. Proc Natl Acad Sci U S A (2014) 111:E3745-54. doi:10.1073/ pnas. 1406768111

4. Brancato A, Plescia F, Marino RAM, Maniaci G, Navarra M, Cannizzaro C. Involvement of dopamine D2 receptors in addictive-like behaviour for acetaldehyde. PLoS One (2014) 9(6):e99454. doi:10.1371/journal.pone. 0099454

5. Cannizzaro C, La Barbera M, Plescia F, Cacace S, Tringali G. Ethanol modulates corticotropin releasing hormone release from the rat hypothalamus: does acetaldehyde play a role? Alcohol Clin Exp Res (2010) 34(4):588-93. doi:10.1111/j.1530-0277.2009.01127.x

6. Cacace S, Plescia F, Barberi I, Cannizzaro C. Acetaldehyde oral self-administration: evidence from the operant-conflict paradigm. Alcohol Clin Exp Res (2012) 36:1278-87. doi:10.1111/j.1530-0277.2011.01725.x

7. Correa M, Salamone JD, Segovia KN, Pardo M, Longoni R, Spina L, et al. Piecing together the puzzle of acetaldehyde as a neuroactive agent. Neurosci Biobehav Rev (2012) 36:404-30. doi:10.1016/j.neubiorev.2011.07.009

8. Plescia F, Brancato A, Marino RAM, Cannizzaro C. Acetaldehyde as a drug of abuse: insight into AM281 administration on operant-conflict paradigm in rats. Front Behav Neurosci (2013) 7:64. doi:10.3389/fnbeh.2013.00064

9. Plescia F, Brancato A, Venniro M, Maniaci G, Cannizzaro E, Sutera FM, et al. Acetaldehyde self-administration by a two-bottle choice paradigm: consequences on emotional reactivity, spatial learning, and memory. Alcohol (2015) 49:139-48. doi:10.1016/j.alcohol.2015.01.002

10. Söderpalm B, Ericson M. Neurocircuitry involved in the development of alcohol addiction: the dopamine system and its access points. Curr Top Behav Neurosci (2013) 13:127-61. doi:10.1007/978-3-642-28720-6_170

11. Koob GF, Roberts AJ, Schulteis G, Parsons LH, Heyser CJ, Hyytiä P, et al. Neurocircuitry targets in ethanol reward and dependence. Alcohol Clin Exp Res (1998) 22(1):3-9. doi:10.1111/j.1530-0277.1998.tb03611.x

12. Olsen RW, Liang J. Role of GABA(A) receptors in alcohol use disorders suggested by chronic intermittent ethanol (CIE) rodent model. Mol Brain (2017) 10(1):45. doi:10.1186/s13041-017-0325-8

13. Van't Veer A, Smith KL, Cohen BM, Carlezon WA Jr, Bechtholt AJ. Kappaopioid receptors differentially regulate low and high levels of ethanol intake in female mice. Brain Behav (2016) 6(9):e00523. doi:10.1002/brb3.523

14. Spoelder M, Hesseling P, Styles M, Baars AM, Lozeman-van't Klooster JG, Lesscher HM, et al. Dopaminergic neurotransmission in ventral and dorsal and behavioral disarrangement as targets for future innovative treatment options.

\section{AUTHOR CONTRIBUTIONS}

VC, AB, GL, AC, and CC wrote major parts of the article. All authors critically reviewed and edited the article. The mini review article was written based on the expertise of the authors, who have sourced the literature on PubMed and Google Scholar.

\section{FUNDING}

This study was supported by research grant 2012-ATE-0167 provided by the University of Palermo, Italy.

striatum differentially modulates alcohol reinforcement. Eur J Neurosci (2017) 45(1):147-58. doi:10.1111/ejn.13358

15. Pina MM, Cunningham CL. Involvement of ventral tegmental area ionotropic glutamate receptors in the expression of ethanol-induced conditioned place preference. Behav Brain Res (2016) 313:23-9. doi:10.1016/j. bbr.2016.06.063

16. Sutera FM, De Caro V, Cannizzaro C, Giannola LI, Lavanco G, Plescia F. Effects of DA-Phen, a dopamine-aminoacidic conjugate, on alcohol intake and forced abstinence. Behav Brain Res (2016) 310:109-18. doi:10.1016/j.bbr.2016.05.006

17. Kirson D, Oleata CS, Parsons LH, Ciccocioppo R, Roberto M. CB(1) and ethanol effects on glutamatergic transmission in the central amygdala of male and female msP and Wistar rats. Addict Biol (2017). doi:10.1111/adb.12525

18. Anderson RI, Becker HC. Role of the dynorphin/kappa opioid receptor system in the motivational effects of ethanol. Alcohol Clin Exp Res (2017) 41(8):1402-18. doi:10.1111/acer.13406

19. Sanchez-Marin L, Pavon FJ, Decara J, Suarez J, Gavito A, Castilla-Ortega E, et al. Effects of intermittent alcohol exposure on emotion and cognition: a potential role for the endogenous cannabinoid system and neuroinflammation. Front Behav Neurosci (2017) 11:15. doi:10.3389/fnbeh.2017.00015

20. Marcinkiewcz CA, Lowery-Gionta EG, Kash TL. Serotonin's complex role in alcoholism: implications for treatment and future research. Alcohol Clin Exp Res (2016) 40(6):1192-201. doi:10.1111/acer.13076

21. Burnett EJ, Chandler LJ, Trantham-Davidson H. Glutamatergic plasticity and alcohol dependence-induced alterations in reward, affect and cognition. Prog Neuropsychopharmacol Biol Psychiatry (2016) 4(65):309-20. doi:10.1016/j. pnpbp.2015.08.012

22. Joffe ME, Grueter CA, Grueter BA. Biological substrates of addiction. Wiley Interdiscip Rev Cogn Sci (2014) 5(2):151-71. doi:10.1002/wcs.1273

23. Adinoff B. Neurobiologic processes in drug reward and addiction. Harv Rev Psychiatry (2004) 12(6):305-20. doi:10.1080/10673220490910844

24. Edwards S, Koob GF. Neurobiology of dysregulated motivational systems in drug addiction. Future Neurol (2010) 5(3):393-401. doi:10.2217/fnl.10.14

25. Ikemoto S. Brain reward circuitry beyond the mesolimbic dopamine system: a neurobiological theory. Neurosci Biobehav Rev (2010) 35(2):129-50. doi:10.1016/j.neubiorev.2010.02.001

26. Di Chiara G, Imperato A. Drugs abused by humans preferentially increase synaptic dopamine concentrations in the mesolimbic system of freely moving rats. Proc Natl Acad Sci U S A (1988) 85:5274-8. doi:10.1073/ pnas.85.14.5274

27. Melis M, Diana M, Enrico P, Marinelli M, Brodie MS. Ethanol and acetaldehyde action on central dopamine systems: mechanisms, modulation, and relationship to stress. Alcohol (2009) 43(7):531-9. doi:10.1016/j.alcohol.2009.05.004

28. Melis M, Carboni E, Caboni P, Acquas E. Key role of salsolinol in ethanol actions on dopamine neuronal activity of the posterior ventral tegmental area. Addict Biol (2015) 1:182-93. doi:10.1111/adb.12097

29. Plescia F, Brancato A, Marino RAM, Vita C, Navarra M, Cannizzaro C. Effect of acetaldehyde intoxication and withdrawal on NPY expression: focus on endocannabinoidergic system involvement. Front Psychiatry (2014) 5:138. doi:10.3389/fpsyt.2014.00138 
30. Metrik J, Spillane NS, Leventhal AM, Kahler CW. Marijuana use and tobacco smoking cessation among heavy alcohol drinkers. Drug Alcohol Depend (2011) 119:194-200. doi:10.1016/j.drugalcdep.2011.06.004

31. Sawicka M, Tracy DK. Naltrexone efficacy in treating alcohol-use disorder in individuals with comorbid psychosis: a systematic review. Ther Adv Psychopharmacol (2017) 7(8-9):211-24. doi:10.1177/2045125317709975

32. Rizzo V, Carletti F, Gambino G, Schiera G, Cannizzaro C, Ferraro G, et al. Role of CB2 receptors and cGMP pathway on the cannabinoid-dependent antiepileptic effects in an in vivo model of partial epilepsy. Epilepsy Res (2014) 108(10):1711-8. doi:10.1016/j.eplepsyres.2014.10.001

33. Carletti F, Ferraro G, Rizzo V, Cannizzaro C, Sardo P. Antiepileptic effect of dymethil sulfoxide in a rat model of temporal lobe epilepsy. Neurosci Lett (2013) 546:31-5. doi:10.1016/j.neulet.2013.04.031

34. Fourgeaud L. Addicted to homer? J Neurosci (2005) 25(42):9555-6. doi:10.1523/JNEUROSCI.3492-05.2005

35. Gass JT, Olive MF. Glutamatergic substrates of drug addiction and alcoholism. Biochem Pharmacol (2008) 75:218-65. doi:10.1016/j.bcp.2007.06.039

36. Volk L, Chiu SL, Sharma K, Huganir RL. Glutamate synapses in human cognitive disorders. Annu Rev Neurosci (2015) 38:127-49. doi:10.1146/ annurev-neuro-071714-033821

37. Bell RL, Hauser SR, McClintick J, Rahman S, Edenberg HJ, Szumlinski KK, et al. Ethanol-associated changes in glutamate reward neurocircuitry: a minireview of clinical and preclinical genetic findings. Prog Mol Biol Transl Sci (2016) 137:41-85. doi:10.1016/bs.pmbts.2015.10.018

38. Cui C, Noronha A, Morikawa H, Alvarez VA, Stuber GD, Szumlinski KK, et al. New insights on neurobiological mechanisms underlying alcohol addiction. Neuropharmacology (2013) 67:223-32. doi:10.1016/j.neuropharm. 2012.09.022

39. Szumlinski KK, Woodward JJ. Glutamate signaling in alcohol abuse and dependence. Neurobiol Alcohol Dependence (2014):173-206. doi:10.1016/ B978-0-12-405941-2.00010-9

40. Chandler LJ. Ethanol and brain plasticity: receptors and molecular networks of the postsynaptic density as targets of ethanol. Pharmacol Ther (2003) 99(3):311-26. doi:10.1016/S0163-7258(03)00096-2

41. Fagni L, Worley PF, Ango F. Homer as both a scaffold and transduction molecule. Sci STKE (2002) 137:8. doi:10.1126/stke.2002.137.re8

42. Fagni L, Ango F, Prezeau L, Worley PF, Pin J, Bockaert J. Control of constitutive activity of metabotropic glutamate receptors by Homer proteins. Int Congr Ser (2003) 1249:245-51. doi:10.1016/S0531-5131(03)00600-9

43. Fagni L, Ango F, Perroy J, Bockaert J. Identification and functional roles of metabotropic glutamate receptor-interacting proteins. Semin Cell Dev Biol (2004) 15(3):289-98. doi:10.1016/j.semcdb.2003.12.018

44. Lum EN, Campbell RR, Rostock C, Szumlinski KK. mGluR1 within the nucleus accumbens regulates alcohol intake in mice under limited-access conditions. Neuropharmacology (2014) 79:679-87. doi:10.1016/j.neuropharm. 2014.01.024

45. Duncan JR, Lawrence AJ. The role of metabotropic glutamate receptors in addiction: evidence from preclinical models. Pharmacol Biochem Behav (2012) 100(4):811-24. doi:10.1016/j.pbb.2011.03.015

46. Mayfield J, Arends MA, Harris RA, Blednov YA. Genes and alcohol consumption: studies with mutant mice. Int Rev Neurobiol (2016) 126:293-355. doi:10.1016/bs.irn.2016.02.014

47. Szumlinski KK, Lominac KD, Oleson EB, Walker JK, Mason A, Dehoff MH, et al. Homer2 is necessary for EtOH-induced neuroplasticity. J Neurosci (2005) 30(25):7054-61. doi:10.1523/JNEUROSCI.1529-05.2005

48. Szumlinski KK, Ary AW, Lominac KD, Klugmann M, Kippin TE. Accumbens Homer2 overexpression facilitates alcohol-induced neuroplasticity in C57BL/6J mice. Neuropsychopharmacology (2008) 33(6):1365-78. doi:10.1038/sj.npp.1301473

49. Cozzoli DK, Courson J, Caruana AL, Miller BW, Greentree DI, Thomspon AB, et al. Nucleus accumbens mGluR5-associated signaling regulates binge alcohol drinking under Drinking-in-the-Dark procedures. Alcohol Clin Exp Res (2012) 36(9):1623-33. doi:10.1111/j.1530-0277.2012.01776.x

50. Haider A, Woodward NC, Lominac KD, Sacramento AD, Klugmann M, Bell RL, et al. Homer2 within the nucleus accumbens core bidirectionally regulates alcohol intake by both P and Wistar rats. Alcohol (2015) 49(6):533-42. doi:10.1016/ j.alcohol.2015.03.009

51. Meyers JL, Salling MC, Almli LM, Ratanatharathorn A, Uddin M, Galea S, et al. Frequency of alcohol consumption in humans; the role of metabotropic glutamate receptors and downstream signaling pathways. Transl Psychiatry (2015) 5:e586. doi:10.1038/tp.2015.70

52. Brakeman PR, Lanahan AA, O'Brien R, Roche K, Barnes CA, Huganir RL, et al. Homer: a protein that selectively binds metabotropic glutamate receptors. Nature (1997) 386:284-8. doi:10.1038/386284a0

53. Klugmann M, Symes CW, Leichtlein CB, Klaussner BK, Dunning J, Fong D, et al. AAV-mediated hippocampal expression of short and long Homer 1 proteins differentially affect cognition and seizure activity in adult rats. Mol Cell Neurosci (2005) 28:347-60. doi:10.1016/j.mcn.2004.10.002

54. Shiraishi-Yamaguchi Y, Furuichi T. The Homer family proteins. Genome Biol (2007) 8(2):206. doi:10.1186/gb-2007-8-2-206

55. Xiao B, Tu JC, Petralia RS, Yuan JP, Doan A, Breder CD, et al. Homer regulates the association of group 1 metabotropic glutamate receptors with multivalent complexes of homer-related, synaptic proteins. Neuron (1998) 21:707-16. doi:10.1016/S0896-6273(00)80588-7

56. Chen T, Fei F, Jiang X, Zhang L, Qu Y, Huo K, et al. Down-regulation of Homer $1 \mathrm{~b} / \mathrm{c}$ attenuates glutamate-mediated excitotoxicity through endoplasmic reticulum and mitochondria pathways in rat cortical neurons. Free Radic Biol Med (2012) 52:208-17. doi:10.1016/j.freeradbiomed.2011.10.451

57. Feng W, Tu J, Yang T, Vernon PS, Allen PD, Worley PF, et al. Homer regulates gain of ryanodine receptor type 1 channel complex. J Biol Chem (2002) 277(47):44722-30. doi:10.1074/jbc.M207675200

58. Lv MM, Cheng YC, Xiao ZB, Sun MY, Ren PC, Sun XD. Down-regulation of Homer $1 \mathrm{~b} / \mathrm{c}$ attenuates group I metabotropic glutamate receptors dependent $\mathrm{Ca} 2+$ signaling through regulating endoplasmic reticulum $\mathrm{Ca} 2+$ release in PC12 cells. Biochem Biophys Res Commun (2014) 450:1568-74. doi:10.1016/j. bbrc.2014.07.044

59. Salanova M, Volpe P, Blottner D. Homer protein family regulation in skeletal muscle and neuromuscular adaptation. IUBMB Life (2013) 65(9):769-76. doi:10.1002/iub.1198

60. Tao-Cheng JH, Thein S, Yang Y, Reese TS, Gallant PE. Homer is concentrated at the postsynaptic density and does not redistribute after acute synaptic stimulation. Neuroscience (2014) 266:80-90. doi:10.1016/j.neuroscience. 2014.01.066

61. Tu JC, Xiao B, Naisbitt S, Yuan JP, Petralia RS, Brakeman P, et al. Coupling of mGluR/Homer and PSD-95 complexes by the shank family of postsynaptic density proteins. Neuron (1999) 23:583-92. doi:10.1016/ S0896-6273(00)80810-7

62. Hayashi MK, Ames HM, Hayashi Y. Tetrameric hub structure of postsynaptic scaffolding protein homer. J Neurosci (2006) 26(33):8492-501. doi:10.1523/ JNEUROSCI.2731-06.2006

63. Xiao B, Tu JC, Worley PF. Homer: a link between neural activity and glutamate receptor function. Curr Opin Neurobiol (2000) 10:370-4. doi:10.1016/ S0959-4388(00)00087-8

64. Sala C, Futai K, Yamamoto K, Worley PF, Hayashi Y, Sheng M. Inhibition of dendritic spine morphogenesis and synaptic transmission by activity-inducible protein Homerla. J Neurosci (2003) 23(15):6327-37.

65. Leber SL, Llenos IC, Miller CL, Dulay JR, Haybaeck J, Weis S. Homer la protein expression in schizophrenia, bipolar disorder, and major depression. J Neural Transm (Vienna) (2017) 124:1261-73. doi:10.1007/s00702-017-1776-x

66. Buscemi L, Ginet V, Lopatar J, Montana V, Pucci L, Spagnuolo P, et al. Homer1 scaffold proteins govern $\mathrm{Ca} 2+$ dynamics in normal and reactive astrocytes. Cereb Cortex (2017) 27(3):2365-84. doi:10.1093/cercor/bhw078

67. Chen T, Yang Y, Luo P, Liu W, Dai S, Zheng X, et al. Homer1 knockdown protects dopamine neurons through regulating calcium homeostasis in an in vitro model of Parkinson's disease. Cell Signal (2013) 25:2863-70. doi:10.1016/j. cellsig.2013.09.004

68. Haas LT, Salazar SV, Kostylev MA, Um JW, Kaufman AC, Strittmatter SM. Metabotropic glutamate receptor 5 couples cellular prion protein to intracellular signalling in Alzheimer's disease. Brain (2016) 139(Pt 2):526-46. doi:10.1093/brain/awv356

69. Grinevich V, Seeburg PH, Schwarz MK, Jezova D. Homer 1 - a new player linking the hypothalamic-pituitary-adrenal axis activity to depression and anxiety. Endocr Regul (2012) 46:153-9. doi:10.4149/endo_2012_03_153

70. Tomasetti C, Iasevoli F, Buonaguro EF, De Berardis D, Fornaro M, Fiengo ALC, et al. Treating the synapse in major psychiatric disorders: the role of postsynaptic density network in dopamine-glutamate interplay and psychopharmacologic drugs molecular actions. Int J Mol Sci (2017) 18(1):135. doi:10.3390/ ijms18010135 
71. Sartor GC, Powell SK, Velmeshev D, Lin DY, Magistri M, Wiedner HJ, et al. Cocaine alters Homer1 natural antisense transcript in the nucleus accumbens. Mol Cell Neurosci (2017) 85:183-9. doi:10.1016/j.mcn.2017.10.003

72. Li Y, Krogh KA, Thayer SA. Epileptic stimulus increases Homer 1a expression to modulate endocannabinoid signaling in cultured hippocampal neurons. Neuropharmacology (2012) 63(6):1140-9. doi:10.1016/j.neuropharm.2012. 07.014

73. Sun P, Wang F, Wang L, Zhang Y, Yamamoto R, Sugai T, et al. Increase in cortical pyramidal cell excitability accompanies depression-like behavior in mice: a transcranial magnetic stimulation study. J Neurosci (2011) 31(45):16464-72. doi:10.1523/JNEUROSCI.1542-11.2011

74. Shui Y, Wang L, Luo X, Uchiumi O, Yamamoto R, Sugai T, et al. Homerla disruption increases vulnerability to predictable subtle stress normally sub-threshold for behavioral changes. Brain Res (2015) 605:70-5. doi:10.1016/j. brainres.2015.02.008

75. Potschka H, Krupp E, Ebert U, Gumbel C, Leichtlein C, Lorch B, et al. Kindling-induced overexpression of homer $1 \mathrm{~A}$ and its functional implications for epileptogenesis. Eur J Neurosci (2002) 16:2157-65. doi:10.1046/j. 1460-9568.2002.02265.x

76. Szumlinski KK, Lominac KD, Kleschen MJ, Oleson EB, Dehoff MH, Schwarz MK, et al. Behavioral and neurochemical phenotyping of Homerl mutant mice: possible relevance to schizophrenia. Genes Brain Behav (2005) 4(5):273-88. doi:10.1111/j.1601-183X.2005.00120.x

77. Lominac KD, Oleson EB, Pava M, Klugmann M, Schwarz MK, Seeburg PH, et al. Distinct roles for different Homerl isoforms in behaviors and associated prefrontal cortex function. J Neurosci (2005) 25(50):11586-94. doi:10.1523/ JNEUROSCI.3764-05.2005

78. Polese D, Amato de Serpis A, Ambesi-Impiombato A, Muscettola G, de Bartolomeis A. Homer la gene expression modulation by antipsychotic drugs: involvement of the glutamate metabotropic system and effects of D-cycloserine. Neuropsychopharmacology (2002) 27:906-13. doi:10.1016/ S0893-133X(02)00371-8

79. de Bartolomeis A, Aloj L, Ambesi-Impiombato A, Bravi D, Curaco C, Muscettola G, et al. Acute administration of antipsychotics modulates homer striatal gene expression differentially. Brain Res Mol Brain Res (2002) 98:124-9. doi:10.1016/S0169-328X(01)00327-8

80. Gao C, Tronson NC, Radulovic J. Modulation of behavior by scaffolding proteins of the post-synaptic density. Neurobiol Learn Mem (2013) 105:3-12. doi:10.1016/j.nlm.2013.04.014

81. Szumlinski KK, Dehoff MH, Kang SH, Frys KA, Lominac KD, Rohrer J, et al. Homer proteins regulate sensitivity to cocaine. Neuron (2004) 43:401-13. doi:10.1016/j.neuron.2004.07.019

82. Szumlinski KK, Kalivas PW, Worley PF. Homer proteins: implications for neuropsychiatric disorders. Curr Opin Neurobiol (2006) 16(3):251-7. doi:10.1016/j.conb.2006.05.002

83. Szumlinski KK, Abernathy KE, Oleson EB, Klugmann M, Lominac KD, He DY, et al. Homer isoforms differentially regulate cocaine-induced neuroplasticity. Neuropsychopharmacology (2006) 31(4):768-77. doi:10.1038/sj.npp.1300890

84. Goulding SP, Obara I, Lominac KD, Gould AT, Miller BW, Klugmann M, et al. Accumbens Homer2-mediated signaling: a factor contributing to mouse strain differences in alcohol drinking? Genes Brain Behav (2011) 10(1):111-26. doi:10.1111/j.1601-183X.2010.00647.x

85. Goulding SP, Szumlinski KK, Contet C, MacCoss MJ, Wu CC. A mass spectrometry-based proteomic analysis of Homer2-interacting proteins in the mouse brain. JProteomics (2017) 166:127-37. doi:10.1016/j. jprot.2017.07.008

86. Cozzoli DK, Goulding SP, Zhang PW, Xiao B, Hu JH, Ary AW, et al. Binge drinking up-regulates accumbens mGluR5-Homer2-PI3K signaling: functional implications for alcoholism. J Neurosci (2009) 29(27):8655-68. doi:10.1523/JNEUROSCI.5900-08.2009

87. Cozzoli DK, Courson J, Wroten MG, Greentree DI, Lum EN, Campbell RR, et al. Binge alcohol drinking by mice requires intact group 1 metabotropic glutamate receptor signaling within the central nucleus of the amygdale. Neuropsychopharmacology (2014) 39(2):435-44. doi:10.1038/npp.2013.214

88. Beckley JT, Laguesse S, Phamluong K, Morisot N, Wegner SA, Ron D. The first alcohol drink triggers mTORC1-dependent synaptic plasticity in nucleus accumbens dopamine D1 receptor neurons. J Neurosci (2016) 36(3):701-13. doi:10.1523/JNEUROSCI.2254-15.2016

89. Obara I, Bell RL, Goulding SP, Reyes CM, Larson LA, Ary AW, et al. Differential effects of chronic ethanol consumption and withdrawal on homer/glutamate receptor expression in subregions of the accumbens and amygdala of $\mathrm{P}$ rats. Alcohol Clin Exp Res (2009) 33(11):1924-34. doi:10.1111/j.1530-0277. 2009.01030.x

90. Lee KM, Coehlo MA, Solton NR, Szumlinski KK. Negative affect and excessive alcohol intake incubate during protracted withdrawal from binge-drinking in adolescent, but not adult, mice. Front Psychol (2017) 8:1128. doi:10.3389/ fpsyg.2017.01128

91. Lee KM, Coelho MA, Sern KR, Szumlinski KK. Homer2 within the central nucleus of the amygdala modulates withdrawal-induced anxiety in a mouse model of binge-drinking. Neuropharmacology (2017) 128:448-59. doi:10.1016/j.neuropharm.2017.11.001

92. Cozzoli DK, Courson J, Rostock C, Campbell RR, Wroten MG, McGregor H, et al. Protein kinase $\mathrm{C}$ epsilon activity in the nucleus accumbens and central nucleus of the amygdala mediates binge alcohol consumption. Biol Psychiatry (2016) 79(6):443-51. doi:10.1016/j.biopsych.2015.01.019

93. Ethell IM, Pasquale EB. Molecular mechanisms of dendritic spine development and remodeling. Prog Neurobiol (2005) 75(3):161-205. doi:10.1016/j. pneurobio.2005.02.003

94. Brancato A, Plescia F, Lavanco G, Cavallaro A, Cannizzaro C. Continuous and intermittent alcohol free-choice from pre-gestational time to lactation: focus on drinking trajectories and maternal behavior. Front Behav Neurosci (2016) 10:31. doi:10.3389/fnbeh.2016.00031

95. Cannizzaro E, Martire M, Gagliano M, Plescia F, La Barbera M, Mantia G, et al. Reversal of prenatal diazepam-induced deficit in a spatial-object learning task by brief, periodic maternal separation in adult rats. Behav Brain Res (2005) 161:320-30. doi:10.1016/j.bbr.2005.02.022

96. Cannizzaro C, Plescia F, Gagliano M, Cannizzaro G, Provenzano G, Mantia G, et al. Effects of pre- and postnatal exposure to 5-methoxytryptamine and early handling on an object-place association learning task in adolescent rat offspring. Neurosci Res (2007) 59(1):74-80. doi:10.1016/j.neures. 2007.05.012

97. Cannizzaro C, Plescia F, Gagliano M, Cannizzaro G, Mantia G, La Barbera M, et al. Perinatal exposure to 5-metoxytryptamine, behavioural-stress reactivity and functional response of 5-HT1A receptors in the adolescent rat. Behav Brain Res (2008) 186(1):98-106. doi:10.1016/j.bbr.2007.07.036

Conflict of Interest Statement: The authors declare that the research was conducted in the absence of any commercial or financial relationships that could be construed as a potential conflict of interest.

Copyright $\odot 2017$ Castelli, Brancato, Cavallaro, Lavanco and Cannizzaro. This is an open-access article distributed under the terms of the Creative Commons Attribution License (CC BY). The use, distribution or reproduction in other forums is permitted, provided the original author(s) or licensor are credited and that the original publication in this journal is cited, in accordance with accepted academic practice. No use, distribution or reproduction is permitted which does not comply with these terms. 